\title{
Systematic Review and Meta-Analysis of Human Skin Diseases Due to Particulate Matter
}

\author{
Le Thi Nhu Ngoc ${ }^{1}$, Duckshin Park ${ }^{2}$, Yongil Lee ${ }^{2}$ and Young-Chul Lee ${ }^{1, *}$ \\ 1 Department of BioNano Technology, Gachon University, 1342 Seongnam, Korea; nhungocle92@gmail.com \\ 2 Korea Railroad Research Institute (KRRI), 176 Cheoldobakmulkwan-ro, Uiwang-si 16105, Korea; \\ dspark@krri.re.kr (D.P.); freego83@krri.re.kr (Y.L.) \\ * Correspondence: dreamdbs@gachon.ac.kr; Tel.: +82-31-750-8751; Fax: +82-31-750-4748
}

Received: 19 October 2017; Accepted: 23 November 2017; Published: 25 November 2017

\begin{abstract}
This study investigated the effects of particulate matter (PM) on human skin diseases by conducting a systematic review of existing literature and performing a meta-analysis. It considered articles reporting an original effect of PM on human skin. From among 918 articles identified, 13 articles were included for further consideration after manual screening of the articles resulted in the exclusion of articles that did not contain data, review articles, editorials, and also articles in languages other than English. Random-effects models and forest plots were used to estimate the effect of PM on the skin by Meta-Disc analysis. According to people's reports of exposure and negative skin effects (atopic dermatitis (AD), eczema, and skin aging, etc.) due to air pollution, the summary relative risk (odds ratio) of $\mathrm{PM}_{10}$ was determined to be 0.99 (95\% confidence interval (CI) 0.89-1.11) whereas $\mathrm{PM}_{2.5}$ was determined to be 1.04 (95\% CI 0.96-1.12). Simultaneously, there was a different extent of impact between $\mathrm{PM}_{10}$ and $\mathrm{PM}_{2.5}$ on atopic dermatitis (AD) for those of young age: the odds ratio of $\mathrm{PM}_{10}$ and $\mathrm{PM}_{2.5}$ were $0.96\left(95 \% \mathrm{CI} 0.83-1.11 ; \mathrm{I}^{2}=62.7 \%\right)$ and 1.05 (95\% CI 0.95-1.16; $\mathrm{I}^{2}=46 \%$ ), respectively. Furthermore, the results suggest an estimated increase of disease incidence per $10 \mu \mathrm{g} / \mathrm{m}^{3} \mathrm{PM}$ of $1.01 \%$ (0.08-2.05) due to $\mathrm{PM}_{10}$ and $1.60 \%$ (0.45-2.82) due to $\mathrm{PM}_{2.5}$. Following the results, $\mathrm{PM}_{10}$ and $\mathrm{PM}_{2.5}$ are associated with increased risks of human skin diseases, especially $\mathrm{AD}$, whose risk is higher in infants and school children. With its smaller size and a high concentration of metals, $\mathrm{PM}_{2.5}$ is more closely related to $\mathrm{AD}$ in younger people, compared to $\mathrm{PM}_{10}$.
\end{abstract}

Keywords: particulate matter (PM); $\mathrm{PM}_{10} ; \mathrm{PM}_{2.5}$; meta-analysis; human skin diseases

\section{Introduction}

Air pollution in both outdoor and indoor environments is a longstanding worldwide issue. Among air pollutants, the most commonly monitored are particulate matter (PM), nitrogen dioxide $\left(\mathrm{NO}_{2}\right)$, sulfur dioxide $\left(\mathrm{SO}_{2}\right)$, and ozone $\left(\mathrm{O}_{3}\right)$. According to the annual report of the World Health Organization (WHO) titled State of Global Air 2017, over $90 \%$ of the world's population live in areas with unhealthy air, which is a leading risk factor for diseases and death [1]. The WHO has established that premature death by air pollution occurs as the direct results of cardiovascular diseases, respiratory diseases, and lung cancer at rates of $80 \%, 14 \%$, and $6 \%$, respectively [2].

One of the most common components of air pollution is PM, which is classified as $\mathrm{PM}_{10}$, fine PM, and ultrafine particles according to the particles' aerodynamic diameter [3]. $\mathrm{PM}_{10}$ (particles of less than $10 \mu \mathrm{m}$ diameter) is composed of particles from dust, industrial emissions, and traffic emissions; such inhalation of $\mathrm{PM}_{10}$ is directly related to various respiratory diseases [4-6]. A smaller PM diameter with less than $2.5 \mu \mathrm{m}$ is defined as fine $\mathrm{PM}\left(\mathrm{PM}_{2.5}\right) ; \mathrm{PM}_{2.5}$ is primarily comprised of organic carbon compounds, nitrates, and sulfates [4]. Recently, ambient $\mathrm{PM}_{2.5}$ has become increasingly present in the surrounding air and significantly involved in human health, particularly in regard to respiratory tract diseases, as it can reach the bronchial tubes and deep regions of the lung [7]. Reference cohort 
studies in which participants are monitored for decades have discovered that smaller particles such as $\mathrm{PM}_{2.5}$ have more adverse effects on human health than larger particles [4,8-10]. Additionally, epidemiological investigations into contamination, especially ambient air pollution, indicated that the $\mathrm{PM}$ is not only correlative with the exacerbation of cardiovascular diseases and respiratory systemic inflammation impacts but also the progression of inflammatory skin diseases [11] such as atopic dermatitis (AD) [12-14], acne, psoriasis, and allergic reactions [9,15-17].

Nowadays, more evidence is available on the effects of $\mathrm{PM}$ of various sizes $\left(\mathrm{PM}_{10}\right.$ and $\left.\mathrm{PM}_{2.5}\right)$ on skin diseases (e.g., AD and eczema in children, cellulitis and skin aging in adult) [10,16-18]. The present study entailed a systematic review and meta-analysis by summarizing the statistically significant effects of PM on human skin and its association with multiple skin diseases and their symptoms.

\section{Materials and Methods}

\subsection{Literature Search and Data Extraction}

The literature search on the adverse skin effects of $\mathrm{PM}_{10}$ and $\mathrm{PM}_{2.5}$ air pollution on the adverse skin effects of $\mathrm{PM}_{10}$ and $\mathrm{PM}_{2.5}$ air pollution was performed in the English-language databases PubMed (National Library of Medicine, Bethesda, MD, USA), Elsevier (Information and Analytics, Amsterdam, the Netherlands), and Web of Science (Institute of Scientific Information and Clarivate Analytics, United States) and considered articles published between 1990 and 2017. Combinations of the following keywords were used: $\mathrm{PM}, \mathrm{PM}_{10}, \mathrm{PM}_{2.5}$, human skin diseases, $\mathrm{AD}$, skin aging, and eczema disease. Reference lists of identified papers were also searched.

Bibliographic reference lists were manually selected for meta-analysis based on identifying associations between $\mathrm{PM}_{10}, \mathrm{PM}_{2.5}$, and human skin diseases, articles that presented no data (e.g., review articles and editorials) as well as articles written in languages other than English were excluded. The inclusion criteria for quantitative meta-analysis were estimates of diseases reporting data that could be used to calculate an estimate of the effect.

From each of the selected studies, the title, author, location, publication year, study design, number of events, and specific risk estimates were extracted and entered into a Microsoft Excel database.

\subsection{Meta-Analysis}

The effect estimates from the selected studies were summarized using the inverse variance method, by which the overall effect estimate was the average of the individual study effect estimates that was weighted by the inverse of the study variance [19]. In our meta-analysis, first, each study's heterogeneity was examined using the standard coefficient heterogeneity $\left(\mathrm{I}^{2}\right)$ test. The existence of heterogeneity was considered at the $95 \%$ level of significance and $\mathrm{I}^{2}$; according to that result, either fixed-effects or random-effects models were used to assess the pooled estimates.

All analyses were performed using Meta-Disc software (version 1.4, Unit of Clinical Biostatistics, Marid, Spain).

\section{Results}

Figure 1 shows the study's article selection process. The database searches yielded a total of 320 unique publications whose titles and abstracts were screened. After exclusion of articles not relevant to the human skin impacts of $\mathrm{PM}_{10}$ and $\mathrm{PM}_{2.5}$, or containing no pertinent data, 13 studies were included in the quantitative meta-analysis. Among them, there was a report of three skin diseases associated with PM [20]: pigment spots, wrinkles, and skin aging; one study described the effect of $\mathrm{PM}$ on two symptoms [16]: eczema and itchy rash; and the influences of both $\mathrm{PM}_{10}$ and $\mathrm{PM}_{2.5}$ on human skin were considered by three studies [21-23]. The 13 studies included 72,000 total participants, with school children and women representing almost all of the participants (see Table 1 for the study's summary characteristic), and all of the studies provided raw data on the effect estimates. 


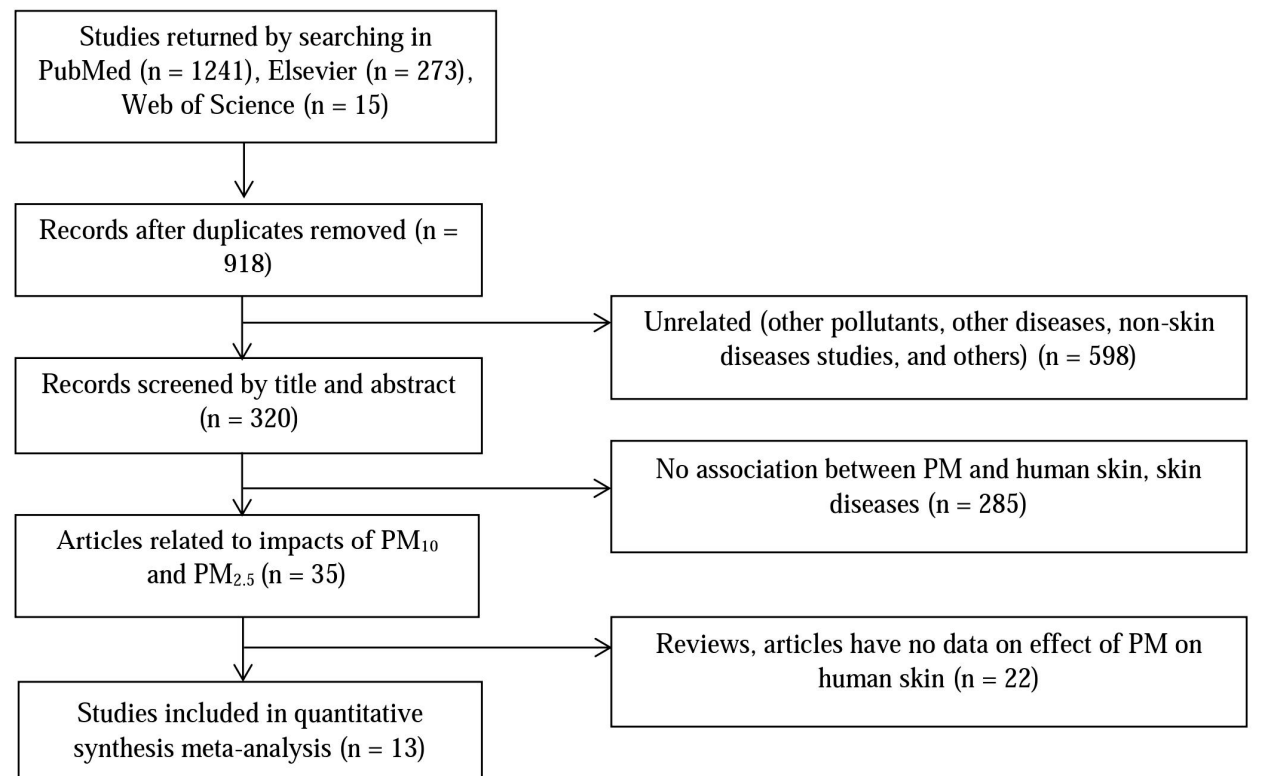

Figure 1. Systematic screening stage for literature review.

Table 1. Summary characteristic of studies. AD: atopic dermatitis; PM: particulate matter.

\begin{tabular}{ccccccc}
\hline Reference & $\begin{array}{c}\text { Year of } \\
\text { Study }\end{array}$ & Location & Pollutant & Diagnosis & Total No. & Age \\
\hline Vierko et al., 2010 [20] & $2008-2009$ & Europe & $\mathrm{PM}_{10}$ & $\begin{array}{c}\text { Pigment spots, } \\
\text { wrinkles, skin aging }\end{array}$ & 400 & $>18$ \\
Song et al., 2011 [23] & 2009 & South Korea & $\mathrm{PM}_{10}, \mathrm{PM}_{2.5}$ & Skin itching & 670 & $8-12$ \\
Peng et al., 2016 [24] & 2015 & China & $\mathrm{PM}_{2.5}$ & Skin itching & 611 & $10-15$ \\
MSa et al., 2013 [25] & 2011 & France & $\mathrm{PM}_{10}$ & Current eczema & 518 & $10-12$ \\
Wang et al., 2015 [21] & 2010 & China & $\mathrm{PM}_{10}$ & AD & 5925 & $8-15$ \\
Morgenstern et al., 2008 [26] & 2005 & Germany & $\mathrm{PM}_{2.5}$ & Eczema & 10,750 & $4-6$ \\
Kim et al., 2013 [27] & $2009-2010$ & South Korea & $\mathrm{PM}_{10}$ & $\mathrm{AD}$ & 1880 & $8-12$ \\
Tang et al., 2017 [22] & 2011 & Taiwan & $\mathrm{PM}_{10}, \mathrm{PM}_{2.5}$ & $\mathrm{AD}$ & 5115 & $20-30$ \\
Shah et al., 2016 [28] & 2015 & United States & $\mathrm{PM}_{10}$ & Eczema & 128 & $28-30$ \\
Brauer et al., 2007 [16] & $2004-2006$ & Germany & $\mathrm{PM}_{2.5}$ & Eczema, itchy rash & 6982 & $3-6$ \\
Lee et al., 2011 [29] & 2010 & South Korea & $\mathrm{PM}_{10}$ & AD & 51 & $2-3$ \\
Gehring et al., 2009 [30] & $1996-2000$ & Netherlands & $\mathrm{PM}_{2.5}$ & Allergen & 3863 & 8 \\
Kim et al., 2017 [31] & $2013-2014$ & South Korea & $\mathrm{PM}_{10}$ & AD & 35,158 & $4-8$ \\
\hline
\end{tabular}

A meta-analysis of these studies yielded summary relative risks (odds ratio) of 0.99 (95\% confidence interval (CI) 0.89-1.11) for $\mathrm{PM}_{10}$ impact and 1.04 (95\% CI 0.96-1.12) for $\mathrm{PM}_{2.5}$ influence. The test for heterogeneity was not significant for either $\mathrm{PM}_{10}\left(\mathrm{I}^{2}=44 \%<50 \%\right)$ or $\mathrm{PM}_{2.5}$ $\left(\mathrm{I}^{2}=48.3 \%<50 \%\right)$. The results of this analysis are provided (Table 2, Figures 2 and 3 ).

Table 2. Sizes of studies in primary meta-analysis. CI: confidence interval.

\begin{tabular}{cccc}
\hline \multirow{2}{*}{ Reference } & \multicolumn{2}{c}{ Odds Ratio (95\% (CI)) } & \multirow{2}{*}{ Diagnosis } \\
\cline { 2 - 3 } & \multicolumn{1}{c}{$\mathbf{P M}_{\mathbf{1 0}}$} & $\mathbf{P M}_{\mathbf{2 . 5}}$ & \\
\hline & $1.08(0.82-1.44)$ & & $\begin{array}{c}\text { Pigment spots } \\
\text { Wrinkles }\end{array}$ \\
Vierko et al., 2010 [20] & $1.01(0.68-1.49)$ & & Skin aging \\
\hline Song et al., 2011 [23] & $1.32(0.93-1.90)$ & & Skin itching \\
Peng et al., 2016 [24] & $1.23(0.79-1.93)$ & $0.67(0.44-1.01)$ & Skin itching \\
\hline
\end{tabular}


Table 2. Cont.

\begin{tabular}{cccc}
\hline \multirow{2}{*}{ Reference } & \multicolumn{2}{c}{ Odds Ratio (95\% (CI)) } & \multirow{2}{*}{ Diagnosis } \\
\cline { 2 - 3 } & PM $_{\mathbf{1 0}}$ & $\mathbf{P M}_{\mathbf{2 . 5}}$ & \\
\hline MSa et al., 2016 [25] & $0.99(0.65-1.51)$ & & Current eczema \\
Wang et al., 2015 [21] & $1.00(0.83-1.21)$ & $1.25(1.00-1.56)$ & AD \\
Morgenstern et al., 2008 [26] & & $0.93(0.82-1.05)$ & Eczema \\
Kim et al., 2013 [27] & $0.76(0.66-0.88)$ & & AD \\
Tang et al., 2017 [22] & $0.98(0.89-1.08)$ & $1.05(0.93-1.19)$ & AD \\
Shah et al., 2016 [28] & $0.87(0.41-1.86)$ & & Eczema \\
\hline Brauer et al., 2007 [16] & & $1.10(0.96-1.25)$ & Eczema \\
\hline Lee et al., 2011 [29] & $1.89(0.76-4.74)$ & & Itchy rash \\
\hline Gehring et al., 2009 [30] & & $1.96(0.82-1.12)$ & AD \\
Kim et al., 2017 [31] & $1.02(0.78-1.31)$ & & Allergen \\
\hline
\end{tabular}

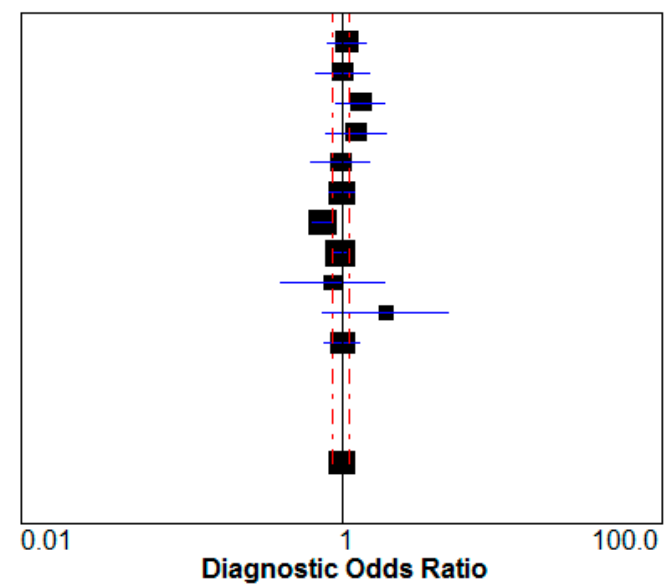

Figure 2. Relative risk of $\mathrm{PM}_{10}$ impact on human skin. OR: odds ratio.

$\begin{array}{lll}\text { Vierko et al. 2010 } & 1.08 & (0.82-1.44) \\ \text { Vierko et al 2010 } & 1.01 & (0.68-1.49) \\ \text { Vierko et al. 2010 } & 1.32 & (0.92-1.90) \\ \text { Song et al. 2010 } & 1.23 & (0.79-1.93) \\ \text { MSa et al. 2013 } & 0.99 & (0.65-1.51) \\ \text { Wang et al. 2016 } & 1.00 & (0.83-1.21) \\ \text { Kim et al. 2013 } & 0.76 & (0.66-0.88) \\ \text { Tang et al. 2017 } & 0.98 & (0.89-1.08) \\ \text { Shah et al. 2016 } & 0.87 & (0.41-1.86) \\ \text { Lee et al. 2011 } & 1.89 & (0.76-4.74) \\ \text { Kim et al. 2017 } & 1.02 & (0.78-1.31) \\ & & \\ \text { Random Effects Model } & & \\ \text { Pooled Diagnostic Odds Ratio }=0.99(0.89 \text { to 1.11) } \\ \text { Cochran-Q }=17.85 ; \text { df }=10(p=0.0576) \\ \text { Inconsistency (I-square })=44.0 \% \\ \text { Tau-Squared }=0.0119\end{array}$

Vierko et al. 2010

Vierko et al 2010

Pooled Diagnostic Odds Ratio $=0.99(0.89$ to 1.11$)$

Cochran- $Q=17.85^{\circ} \cdot \mathrm{df}=10(\mathrm{p}=0.0576)$

Tau-squared $=0.0119$

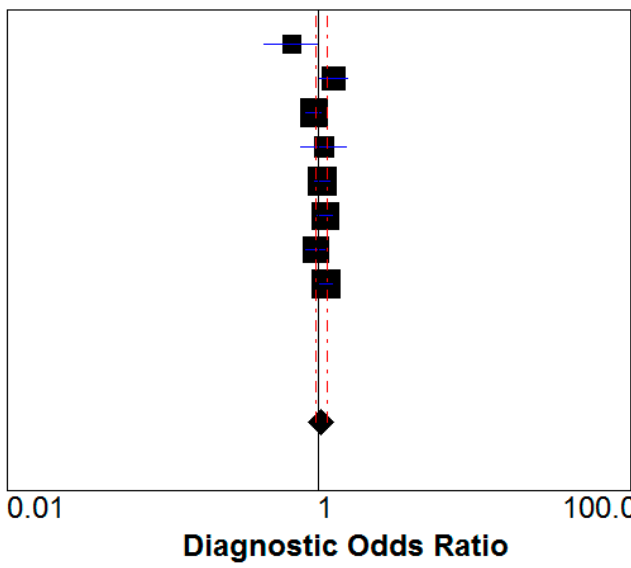

Figure 3. Relative risk of $\mathrm{PM}_{2.5}$ impact on human skin.
Diagnostic OR (95\% CI)

Song et al. 2017 Wang et al. 2016

Morgenstern et al. 2008

Peng et al. 2016

Tang et al. 2017

Brauer et al. 2007

Brauer et al. 2007

Gehring et al. 2009

$0.67 \quad(0.44-1.01)$

$1.25 \quad(1.00-1.56)$

$0.93 \quad(0.82-1.05)$

$1.08 \quad(0.77-1.52)$

$1.05 \quad(0.93-1.19)$

$1.10 \quad(0.96-1.25)$

$0.96 \quad(0.82-1.12)$

$1.11 \quad(1.00-1.24)$

\section{Random Effects Model}

Pooled Diagnostic Odds Ratio $=1.04(0.96$ to 1.12$)$

Cochran- $Q=13.53 ; \mathrm{df}=7(p=0.0602)$

Inconsistency (I-square) $=48.3 \%$

Tau-squared $=0.0058$

Furthermore, to assess the impact of PM on the skin in those of a young age, particularly for $\mathrm{AD}$ disease, a sub-analysis of studies was performed that included the influence estimates for different sized PM. The results indicated that $\mathrm{PM}_{2.5}$ is directly related to AD in young people (Table 3 ), showing an odds ratio of 1.05 (95\% CI 0.95-1.16) and coefficient heterogeneity $\left(\mathrm{I}^{2}\right)$ of $46 \%$; in contrast, 
the heterogeneity was significant for the $\mathrm{PM}_{10}$ effect, showing an odds ratio of 0.96 (95\% CI 0.83-1.11) and $\mathrm{I}^{2}$ of $62.7 \%>50 \%$.

Table 3. Impact of PM on $\mathrm{AD}$ * for those young age.

\begin{tabular}{ccc}
\hline \multirow{2}{*}{ Reference } & \multicolumn{2}{c}{ Odds Ratio (95\% CI) } \\
\cline { 2 - 3 } & PM $_{\mathbf{1 0}}$ & $\mathbf{P M}_{\mathbf{2 . 5}}$ \\
\hline Song et al., 2011 [23] & $1.23(0.79-1.93)$ & $0.67(0.44-1.01)$ \\
Wang et al., 2015 [21] & $1.00(0.83-1.21)$ & $1.25(1.00-1.56)$ \\
Peng et al., 2016 [24] & & $1.08(0.77-1.52)$ \\
Kim et al., 2013 [27] & $0.76(0.66-0.88)$ & \\
Tang et al., 2017 [22] & $0.98(0.89-1.08)$ & $1.05(0.93-1.19)$ \\
Brauer et al., 2007 [16] & & $0.96(0.82-1.12)$ \\
Lee et al., 2017 [29] & $1.89(0.76-4.74)$ & \\
Kim et al., 2017 [31] & $1.02(0.78-1.31)$ & \\
Gehring et al., 2009 [30] & & $1.11(1.00-1.24)$ \\
Summary relative risk (95\% CI) & $0.96(0.83-1.11)$ & $1.05(0.95-1.16)$ \\
The coefficient heterogeneity I I $^{2}(\%)$ & 62.7 & 46.0 \\
\hline
\end{tabular}

* AD included AD, skin itching, general allergens, and itchy rash.

Estimates of the effects of short-term exposure to $\mathrm{PM}_{10}$ and $\mathrm{PM}_{2.5}$ were analyzed on the basis of increase incidence of skin diseases per $10 \mu \mathrm{g} / \mathrm{m}^{3}$ increase in $\mathrm{PM}_{10}$ and $\mathrm{PM}_{2.5}$. For each increase in $\mathrm{PM}_{10}$ and $\mathrm{PM}_{2.5}$ concentration, the risk of human skin diseases due to PM was determined to be $1.01 \%$ (0.08-2.05) and 1.60\% (0.45-2.82), respectively. The results are presented in Table 4.

Table 4. ER (\%) of skin diseases due to short-term exposure to PM.

\begin{tabular}{ccccc}
\hline Reference & Location & Diagnosis & \multicolumn{2}{c}{ ER (\%) Skin Disease (95\% CI) } \\
\cline { 4 - 5 } & & & PM $_{\mathbf{1 0}}$ & PM $_{\mathbf{2 . 5}}$ \\
\hline Kim et al., 2013 [27] & South Korea & AD & $0.44(0.12-0.77)$ & $0.67(0.03-1.38)$ \\
Wang et al., 2015 [21] & China & AD & & $1.54(1.03-2.32)$ \\
Kim et al., 2017 [31] & South Korea & AD & $3.20(1.50-4.90)$ & \\
Morgenstern et al., 2008 [26] & Europe & Eczema & & $1.00(0.97-1.04)$ \\
Song et al., 2011 [23] & South Korea & Skin itching & $1.03(0.02-2.23)$ & $3.10(0.20-6.10)$ \\
Kim et al., 2017 [31] & South Korea & AD & $0.36(0.05-0.71)$ & \\
Msa et al., 2013 [25] & France & Eczema & $1.02(0.84-1.24)$ & \\
Seo et al., 2015 [9] & South Korea & AD & $0.57(0.23-0.98)$ & \\
Gehring et al., 2010 [30] & Netherlands & Allergen & & $1.68(0.41-2.07)$ \\
Ahn Kangmo, 2015 [12] & South Korea & AD & $0.44(0.16-0.74)$ & \\
\hline \multicolumn{2}{c}{ Combined estimate } & & $1.01(0.08-2.05)$ & $1.60(0.45-2.82)$ \\
\hline
\end{tabular}

ER (\%): Excess risk: percent increase skin disease (95\% CI) per $10 \mu \mathrm{g} / \mathrm{m}^{3}$ increase in $\mathrm{PM}_{10}$ and $\mathrm{PM}_{2.5}$.

The relationship between concentrations of PM and human skin diseases over long-term exposure is presented in Table 5. The outcomes showed that when concentrations reach upwards of $47.09 \mu \mathrm{g} / \mathrm{m}^{3}$ for $\mathrm{PM}_{10}$ and $26.04 \mu \mathrm{g} / \mathrm{m}^{3}$ for $\mathrm{PM}_{2.5}$ human skin could be adversely affected.

Table 5. Relationship between PM concentration and human skin diseases over long-term exposure.

\begin{tabular}{|c|c|c|c|c|}
\hline \multirow{2}{*}{ Reference } & \multirow{2}{*}{ Location } & \multirow{2}{*}{ Diagnosis } & \multicolumn{2}{|c|}{ Pollutant } \\
\hline & & & $\mathrm{PM}_{10}\left(\mu \mathrm{g} / \mathrm{m}^{3}\right)$ & $\mathrm{PM}_{2.5}\left(\mu \mathrm{g} / \mathrm{m}^{3}\right)$ \\
\hline Vierkotter et al., 2010 [20] & Germany & Skin aging & & 6.50 \\
\hline Gehring et al., 2010 [30] & Netherlands & Allergen & & 25.20 \\
\hline Kim et al., 2013 [27] & South Korea & $\mathrm{AD}$ & 50.50 & 25.60 \\
\hline Peng et al., 2016 [24] & China & Skin itching & & 35.20 \\
\hline
\end{tabular}


Table 5. Cont.

\begin{tabular}{|c|c|c|c|c|}
\hline \multirow{2}{*}{ Reference } & \multirow{2}{*}{ Location } & \multirow{2}{*}{ Diagnosis } & \multicolumn{2}{|c|}{ Pollutant } \\
\hline & & & $\mathrm{PM}_{10}\left(\mu \mathrm{g} / \mathrm{m}^{3}\right)$ & $\mathrm{PM}_{2.5}\left(\mu \mathrm{g} / \mathrm{m}^{3}\right)$ \\
\hline Wang et al., 2015 [21] & China & $\mathrm{AD}$ & 48.32 & 29.07 \\
\hline Shah et al., 2016 [28] & United States & Eczema & 56.26 & \\
\hline Kim et al., 2017 [31] & South Korea & $\mathrm{AD}$ & 45.20 & \\
\hline Brauer et al., 2007 [16] & Netherlands & Eczema & & 25.20 \\
\hline Morgenstern et al., 2008 [26] & Europe & Eczema & & 15.13 \\
\hline Song et al., 2011 [23] & South Korea & Skin itching & 44.89 & 22.38 \\
\hline Tang et al., 2016 [22] & Taiwan & $\mathrm{AD}$ & 56.30 & 33.60 \\
\hline Msa et al., 2013 [25] & France & Eczema & 31.00 & \\
\hline Seo et al., 2015 [9] & South Korea & $\mathrm{AD}$ & 46.80 & \\
\hline \multirow{3}{*}{ Szyszkowicz et al., 2016 [17] } & New York & & & 27.00 \\
\hline & Hamilton & Cellulitis & & 33.50 \\
\hline & Halton & & & 34.20 \\
\hline \multicolumn{2}{|c|}{ Combined estimate } & & $\begin{array}{c}47.09 \\
(42.01-52.17)\end{array}$ & $\begin{array}{c}26.04 \\
(20.66-31.42)\end{array}$ \\
\hline
\end{tabular}

\section{Discussion}

In this systematic review and meta-analysis of more than 46,100 cases of PM impact on human skin from 13 studies, this study confirmed that both $\mathrm{PM}_{10}$ and $\mathrm{PM}_{2.5}$ have a statistically significant impact on skin diseases. Moreover, referencing estimates of the WHO and studies related to the impacts of PM to health [32-34], PM not only causes usual skin diseases but may also lead to skin cancer (basal cell carcinoma and squamous cell carcinoma) [35] and other health issues (e.g., cardiovascular disease, respiratory system, and asthma $[4,16])$.

In this study, it was found that PM is closely associated with AD, eczema, and skin allergies. In Figure 4, a high sensitivity can be observed for the influences of both PM types on human, which is compelling evidence of an association between air pollution and human skin diseases.

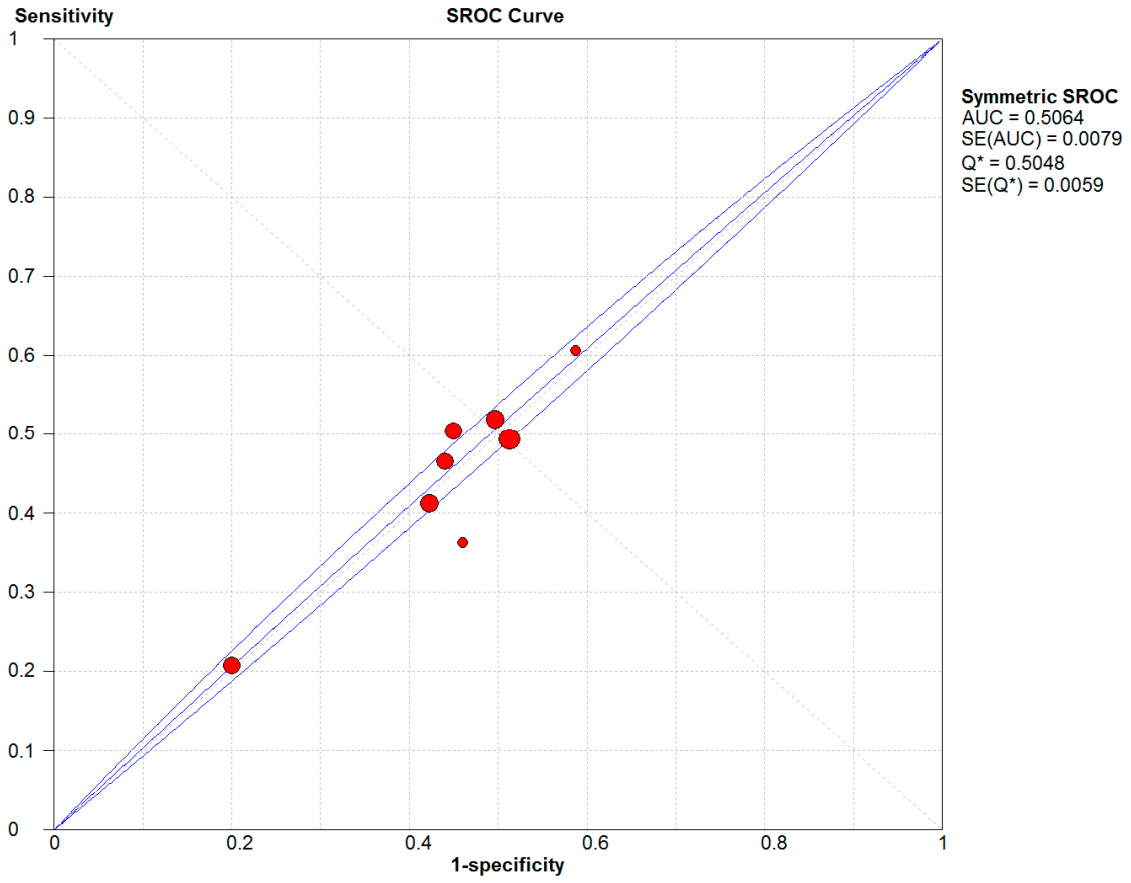

(a)

Figure 4. Cont. 


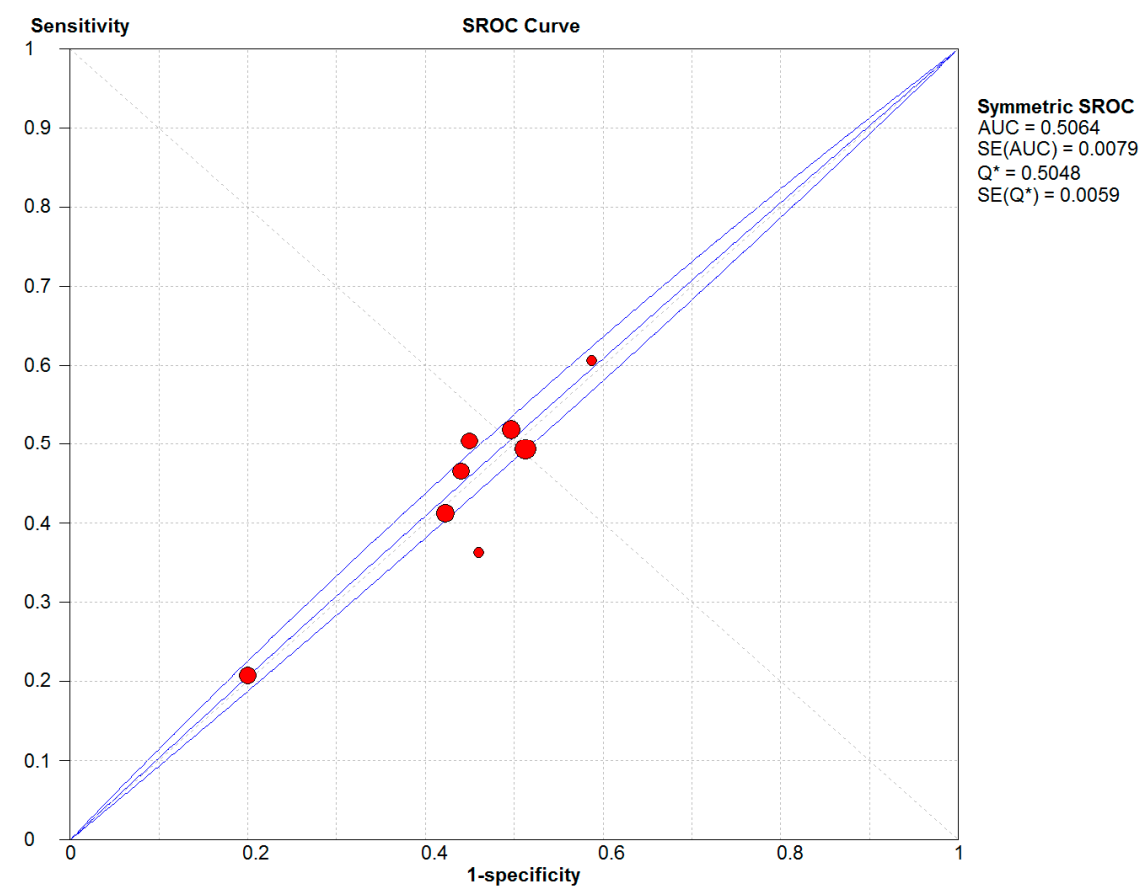

(b)

Figure 4. Summary receiver operating characteristic (SROC) curves of influences of (a) $\mathrm{PM}_{2.5}$, (b) $\mathrm{PM}_{10}$ on human skin.

Furthermore, the results demonstrated that with each $10 \mu \mathrm{g} / \mathrm{m}^{3}$ increase, $\mathrm{PM}_{10}$ and $\mathrm{PM}_{2.5}$ increased disease incidences by $1.01 \%(0.08-2.05)$ and $1.60 \%(0.45-2.82)$, respectively (Table 4$)$. The outcomes suggest that an increase in $\mathrm{PM}_{2.5}$ exposure concentration could slightly elevate the incidence of skin disease compared to $\mathrm{PM}_{10}$. PMs differ not only according to their varying physical and chemical characteristic but also their concentrations by location (e.g., components, sources, structure, surface, and diameter, etc.) [36,37]. In general, $\mathrm{PM}_{10}$ and $\mathrm{PM}_{2.5}$ include inhalable particles that are small enough to penetrate deep into skin and regions of the respiratory system, especially as a consequence of long-term exposure. Humans are at risk of a greater incidence of diseases due to lower $\mathrm{PM}_{2.5}$ concentrations $\left(26.04 \mu \mathrm{g} / \mathrm{m}^{3}\right)$ than $\mathrm{PM}_{10}$ concentrations $\left(47.09 \mu \mathrm{g} / \mathrm{m}^{3}\right)$; the results of this study indicated that $\mathrm{PM}_{2.5}$ was significantly more harmful to human health than $\mathrm{PM}_{10}$ [36].

Additionally, according to the results (Table 6), these estimates demonstrated a larger impact of PM to skin allergies, which demonstrated $54 \%$ sensitivity. Even though the estimates showed lower sensitivities for $\mathrm{AD}$ and eczema disease ( $26 \%$ and $47 \%$ sensitivity, respectively), there were more cases of these skin conditions than skin allergies, particularly among children and infants $[16,29,31]$.

Table 6. Summary sensitivity and specificity of AD, eczema disease, and skin allergies due to PM.

\begin{tabular}{ccccc}
\hline Category & No. of Studies & $\begin{array}{c}\text { Summary Sensitivity, \% } \\
(\mathbf{9 5 \%} \text { CI) }\end{array}$ & $\begin{array}{c}\text { Summary Specificity, \% } \\
(\mathbf{9 5 \%} \text { CI) }\end{array}$ & Q * (\%) \\
\hline AD & 7 & $26.4(25.5-27.4)$ & $46.5(46.1-46.9)$ & 50.25 \\
Eczema & 4 & $47.2(45.2-49.3)$ & $50.5(49.8-51.2)$ & 50.09 \\
Skin allergen & 6 & $54.3(51.3-57.3)$ & $49.5(47.7-51.3)$ & 49.76 \\
\hline
\end{tabular}

$\mathrm{Q}^{*}$ corresponds to the point on the SROC curve where sensitivity and specificity are equal.

Most of the subjects in all of the studies were young (2-30 years old), including newborns, children, and adolescents. Indeed, the skin of individuals in these age groups is sensitive, resulting in a higher likelihood of effects due to exposure to air pollution. Long-term exposure to air-pollution sources (e.g., smoking, $\mathrm{PM}, \mathrm{NO}_{2}, \mathrm{SO}_{2}$, etc.) in the home, outdoors, and at school contributes to many health 
problems such as wheezing and asthma as well as cardiovascular and skin diseases (e.g., cellulitis, skin itching, itchy aging, AD, etc.) $[17,26,31,38]$.

The coefficient heterogeneity $\left(\mathrm{I}^{2}=46 \%\right)$ from the results of the meta-analysis demonstrated the presence of high concentrations of $\mathrm{PM}_{2.5}$ in the air, which was one of the direct causes of $\mathrm{AD}$ in the younger age groups, particularly newborns and children. Furthermore, heterogeneity existed for the influence of $\mathrm{PM}_{10}\left(\mathrm{I}^{2}=62.7 \%>50 \%\right)$, but it is not easy to include or exclude the causal effect of $\mathrm{PM}_{10}$ on $\mathrm{AD}$ diseases, as more research is needed in order to obtain better statistical evidence and an enhanced understanding of that possible association. In particular, higher contents of cadmium, copper, lead, nickel, vanadium, and zinc in $\mathrm{PM}_{2.5}$ were associated with increased eczema prevalence and $\mathrm{AD}$ [38], and the ratio of heavy metals in PM was more abundant in $\mathrm{PM}_{2.5}$ than in $\mathrm{PM}_{10}$ [39], thus contributing towards making $\mathrm{PM}_{2.5}$ potentially more harmful to humans than $\mathrm{PM}_{10}$, specifically via oxidative stress. Therefore, the next standard will have to focus on smaller particles that are more likely to be responsible for adverse health effects.

\section{Conclusions}

Observationally, PM is one of the most common components of air pollution. There is evidence that metals in PM cause DNA, skin-cell, and protein damage as well as apoptosis through the mitochondria-regulated death pathway [39]. $\mathrm{PM}_{10}$ and $\mathrm{PM}_{2.5}$ in high concentrations can promote the development and exacerbation of various skin diseases. Based on these meta-analysis results, it can be added that there are associations between $\mathrm{PM}_{10}, \mathrm{PM}_{2.5}$, and skin diseases, and furthermore, that there is an increased probability of PM-associated diseases at young ages.

The major differences between the two particulate fractions are in the number, concentration, and composition of the smallest particles [40]. $\mathrm{PM}_{2.5}$, with its smaller size and a larger number of component metals, can easily penetrate deep into skin cells, and, as such, can pose a higher risk of $\mathrm{AD}$ disease than $\mathrm{PM}_{10} ; \mathrm{PM}_{2.5}$ thus has a major role in adverse impacts of air pollution on human health [41]. Therefore, $\mathrm{PM}_{2.5}$ might be more closely associated with PM-induced skin diseases.

Even though PM has general diameter and mass concentration standards associated with skin diseases in humans, PM has varying physical and chemical characteristics, hence monitoring of $\mathrm{PM}_{10}$ and $\mathrm{PM}_{2.5}$ needs to be improved in many countries to asses population exposure and to assist local authorities in establishing plans for improving air quality (limits for emissions from various sources, reducing energy consumption, and changing modes of transport, etc.) [36] so that we can control not only human skin diseases but also many serious diseases (e.g., lung cancer, cardiovascular diseases, and respiratory diseases, etc.) due to PM exposure.

\section{Limitations of Study}

A limitation of this study is the fact that it included only observational, cohort studies, and individual studies and only small quantities of those; therefore, we could not clearly delineate the relationships among PM, air pollution, and human skin diseases. In the future, if there are cohort studies and/or case-control studies about the impact of PM on skin human diseases, more significance and greater confidence can be placed on determining the degree of impact from different relevant variables.

Acknowledgments: This work was supported by research grants for the Railway Technology Research Project from the Ministry of Land, Infrastructure and Transport, Republic of Korea (17RTRP-B082486-04) and by the Korean Ministry of Environment's “GAIA project (2015000550006)".

Author Contributions: Young-Chul Lee planned the study and contributed the main ideas; Le Thi Nhu Ngoc collected the data and Le Thi Nhu Ngoc and Young-Chul Lee were principally responsible for the writing of the manuscript; Young-Chul Lee, Duckshin Park, and Yongil Lee commented on and revised the manuscript.

Conflicts of Interest: The authors declare that they have no competing interests. 


\section{References}

1. SOGA. State of Global Air. A Special Report on Global Exposure to Air Pollution and Its Disease Burden; Health Effects Institute: Cambridge, MA, USA, 2017; pp. 1-15.

2. WHO. Ambient (Outdoor) Air Quality and Health. Available online: http://www.who.int/mediacentre/ factsheets / fs313/en/ (accessed on 5 July 2017).

3. Carlsten, C.; Melén, E. Air pollution, genetics, and allergy: An update. Curr. Opin. Allergy Clin. Immunol. 2012, 12, 455-460. [CrossRef] [PubMed]

4. Noh, J.; Sohn, J.; Cho, J.; Cho, S.K.; Choi, Y.J.; Kim, C.; Shin, D.C. Short-term effects of ambient air pollution on emergency department visits for asthma: An assessment of effect modification by prior allergic disease history. J. Prev. Med. Public Health 2016, 49, 329-341. [CrossRef] [PubMed]

5. Cao, L.; Zeng, J.; Liu, K.; Bao, L.; Li, Y. Characterization and cytotoxicity of $\mathrm{PM}_{<0.2}, \mathrm{PM}_{0.2-2.5}$ and $\mathrm{PM}_{2.5-10}$ around mswi in Shanghai, China. Int. J. Environ. Res. Public Health 2015, 12, 5076-5089. [CrossRef]

6. Vu, V.T.; Lee, B.K.; Kim, J.T.; Lee, C.H.; Kim, I.H. Assessment of carcinogenic risk due to inhalation of polycyclic aromatic hydrocarbons in $\mathrm{PM}_{10}$ from an industrial city: A Korean case-study. J. Hazard. Mater. 2011, 189, 349-356. [CrossRef] [PubMed]

7. Sorensen, M.; Daneshvar, B.; Hansen, M.; Dragsted, L.O.; Hertel, O.; Knudsen, L.; Loft, S. Personal PM2.5 exposure and markers of oxidative stress in blood. Environ. Health Perspect. 2003, 111, 161-166. [CrossRef] [PubMed]

8. Kim, K.E.; Choi, D.; Park, H.J. Air pollution and skin diseases: Adverse effects of airborne PM on various skin diseases. Life Sci. 2016, 152, 126-134. [CrossRef] [PubMed]

9. Seo, S.C.; Kim, D.; Min, S.; Paul, C.; Yoo, Y.; Choung, J.T. Gis-based association between PM 10 and allergic diseases in seoul: Implications for health and environmental policy. Ann. Allergy Asthma Immunol. 2016, 8, 32-40. [CrossRef]

10. Achilleos, S.; Kioumourtzoglou, M.A.; Wu, C.D.; Schwartz, J.D.; Koutrakis, P.; Papatheodorou, S.I. Acute effects offine particulate matter constituents on mortality: A systematic review and meta-regression analysis. Environ. Int. 2017, 109, 89-100. [CrossRef] [PubMed]

11. Krutmann, J.; Liu, W.; Li, L.; Pan, X.; Crawford, M.; Sore, G.; Seite, S. Pollution and skin: From epidemiological and mechanistic studies to clinical implications. J. Dermatol. Sci. 2014, 76, 163-168. [CrossRef] [PubMed]

12. Ahn, K. The role of air pollutants in atopic dermatitis. J. Allergy Clin. Immunol. 2014, 134, 993-999. [CrossRef] [PubMed]

13. Kim, E.H.; Kim, S.; Lee, J.H.; Kim, J.; Han, Y.; Kim, Y.M.; Kim, G.B.; Jung, K.; Cheong, H.K.; Ahn, K. Indoor air pollution aggravates symptoms of atopic dermatitis in children. PLoS ONE 2015, 10, e0119501. [CrossRef] [PubMed]

14. Lee, J.H.; Lee, H.S.; Park, M.R.; Lee, S.W.; Kim, E.H.; Cho, J.B.; Kim, J.; Han, Y.; Jung, K.; Cheong, H.K.; et al. Relationship between indoor air pollutant levels and residential environment in children with atopic dermatitis. Ann. Allergy Asthma Immunol. 2014, 6, 517-524. [CrossRef] [PubMed]

15. Annesi-Maesano, I.; Moreau, D.; Caillaudc, D.; Lavaudd, F.O.; Moullece, Y.L.; Taytar, A.; Paulig, G.; Charpinh, D. Residential proximity fine particles related to allergic sensitisation and asthma in primary school children. Respir. Med. 2007, 101, 1721-1729. [CrossRef] [PubMed]

16. Brauer, M.; Hoek, G.; Smit, H.A.; Jongste, J.C.D.; Gerritsen, J.; Postmae, D.S.; Kerkhof, M.; Brunekreef, B. Air pollution and development of asthma, allergy and infections in a birth cohort. Eur. Respir. J. 2007, 29, 879-888. [CrossRef] [PubMed]

17. Szyszkowicz, M.; Kousha, T.; Valacchi, G. Ambient air pollution and emergency department visits for skin conditions. Glob. Dermatol. 2016, 3, 323-329. [CrossRef]

18. Weinmayr, G.; Romeo, E.; Sario, M.D.; Weiland, S.K.; Forastiere, F. Short-term effects of $\mathrm{PM}_{10}$ and $\mathrm{NO}_{2}$ on respiratory health among children with asthma or asthma-like symptoms: A systematic review and meta-analysis. Environ. Health Perspect. 2010, 118, 449-457. [CrossRef] [PubMed]

19. DerSimonian, R.; Laird, N. Meta-analysis in clinical trials revisited. Contemp. Clin. Trials 2015, 45, 139-145. [CrossRef] [PubMed]

20. Vierko, A.; Schikowski, T.; Ranft, U.; Sugiri, D.; Matsui, M.; Kramer, U.; Krutmann, J. Airborne particle exposure and extrinsic skin aging. J. Investig. Dermatol. 2010, 130, 2719-2726. [CrossRef] [PubMed] 
21. Wang, I.J.; Tung, T.H.; Tangd, C.S.; Zhao, Z.H. Allergens, air pollutants, and childhood allergic diseases. Int. J. Hyg. Environ. Health 2015, 219, 66-71. [CrossRef] [PubMed]

22. Tang, K.T.; Ku, K.C.; Chen, D.Y.; Lin, C.H.; Tsuang, B.J.; Chen, Y.H. Adult atopic dermatitis and exposure to air pollutants-A nationwide population-based study. Ann. Allergy Asthma Immunol. 2017, 118, 351-355. [CrossRef] [PubMed]

23. Song, S.; Lee, K.; Lee, Y.M.; Lee, J.H.; Lee, S.; Yu, Y.D.; Paek, D. Acute health effects of urban fine and ultrafine particles on children with atopic dermatitis. Environ. Res. 2011, 111, 394-399. [CrossRef] [PubMed]

24. Peng, F.; Xue, C.H.; Hwang, S.K.; Li, W.H.; Chen, Z.; Zhang, J.Z. Exposure to fine PM associated with senile lentigo in chinese women: A cross-sectional study. J. Eur. Acad. Dermatol. Venereol. 2016, 31, 355-360. [CrossRef] [PubMed]

25. MSa, C.Z.; Baïz, N.; Banerjee, S.; Charpin, D.A.; Caillaud, D.; Blay, F.D.; Raherison, C.; Lavaud, F.; Annesi-Maesano, I. The relationships between ambient air pollutants and childhood asthma and eczema are modified by emotion and conduct problems. Ann. Epidemiol. 2013, 23, 773-788. [CrossRef]

26. Morgenstern, V.; Zutavern, A.; Cyrys, J.; Brockow, I.; Koletzko, S.; Krämer, U.; Behrendt, H.; Herbarth, O.; Berg, A.V.; Bauer, C.P.; et al. Atopic diseases, allergic sensitization, and exposure to traffic-related air pollution in children. ATS J. 2008, 135, 135-140. [CrossRef] [PubMed]

27. Kim, J.; Kim, E.H.; Oh, I.; Jung, K.; Han, Y.S.; Cheong, H.K.; Ahn, K. Symptoms of atopic dermatitis are influenced by outdoor air pollution. J. Allergy Clin. Immunol. 2013, 1332, 495-498. [CrossRef] [PubMed]

28. Shah, L.; Mainelis, G.; Ramagopal, M.; Black, K.; Shalat, S.L. Use of a robotic sampler (piper) for evaluation of PM exposure and eczema in preschoolers. Int. J. Environ. Res. Public Health 2016, 13, 242. [CrossRef] [PubMed]

29. Lee, J.H.; Kim, J.; Lee, S.W.; Suh, J.; Yu, J.S.; Park, E.; Lee, J.; Kim, H.; Lee, K.S.; Chang, E.Y.; et al. The clinical effects of hospitalization in a low pollutant room on atopic dermatitis. Asia Pac. Allergy 2011, 1, 87-92. [CrossRef] [PubMed]

30. Gehring, U.; Wijga, A.H.; Brauer, M.; Fischer, P.; de Jongste, J.C.; Kerkhof, M.; Oldenwening, M.; Smit, H.A.; Brunekreef, B. Traffic-related air pollution and the development of asthma and allergies during the first 8 years of life. Am. J. Respir. Crit. Care Med. 2009, 181, 596-603. [CrossRef] [PubMed]

31. Kim, Y.M.; Kim, J.; Han, Y.; Jeon, B.H.; Cheong, H.K.; Ahn, K. Short-term effects of weather and air pollution on atopic dermatitis symptoms in children: A panel study in Korea. PLoS ONE 2017, 18, 210-218. [CrossRef] [PubMed]

32. Lai, H.K.; Tsang, H.; Wong, C.M. Meta-analysis of adverse health effects due to air pollution in Chinese populations. BMC Public Health 2013, 13, 360-372. [CrossRef] [PubMed]

33. Magnani, N.D.; Muresan, X.M.; Belmonte, G.; Cervellati, F.; Sticozzi, C.; Pecorelli, A.; Miracco, C.; Marchini, T.; Evelson, P.; Valacchi, G. Skin damage mechanisms related to airborne PM exposure. Toxicol. Sci. 2016, 149, 227-236. [CrossRef] [PubMed]

34. Pan, T.L.; Wang, P.W.; Aljuffali, I.A.; Huang, C.T.; Lee, C.W.; Fang, J.Y. The impact of urban particulate pollution on skin barrier function and the subsequent drug absorption. J. Dermatol. Sci. 2015, 78, 51-60. [CrossRef] [PubMed]

35. Wehner, M.R.; Phil, M.; Shive, M.L.; Chren, M.M.; Han, J.; Qureshi, A.A.; Linos, E. Indoor tanning and non-melanoma skin cancer: Systematic review and meta-analysis. BMJ-Br. Med. J. 2012, 345, 590-599. [CrossRef]

36. WHO. Health Effects of Particulate Matter. 2013. Available online: http://www.euro.who.int/_data/assets / pdf_file/0006/189051/Health-effects-of-particulate-matter-final-Eng.pdf (accessed on 16 November 2017).

37. EPA; Agency, U.S.E.P. Particulate Matter Concentrations. 2014. Available online: https://www.epa.gov/roe (accessed on 17 November 2017).

38. Kathuria, P.; Silverberg, J.I. Association of pollution and climate with atopic eczema in US children. Pediatr. Allergy Immunol. 2016, 27, 478-485. [CrossRef] [PubMed]

39. Choi, J.H.; Kim, J.S.; Kim, Y.C.; Kim, Y.S.; Chung, N.H.; Cho, M.H. Comparative study of PM $2.5-$ And $^{2}$ $\mathrm{PM}_{10}$-Induced oxidative stress in rat lung epithelial cells. J. Vet. Sci. 2004, 5, 11-18. Available online: https:/ / www.ncbi.nlm.nih.gov / pubmed/15028881 (accessed on 15 May 2017). 
40. Diociaiuti, M.; Balduzzi, M.; Berardis, B.D.; Cattani, G.; Stacchini, G.; Ziemacki, G.; Marconi, A.; Paoletti, L. The two $\mathrm{PM}_{2.5}$ (fine) and $\mathrm{PM}_{2.5-10}$ (coarse) fractions: Evidence of different biological activity. Environ. Res. 2011, 86, 254-262. [CrossRef]

41. Chen, R.; Hu, B.; Liu, Y.; Xu, J.; Yang, G.; Xu, D.; Chen, C. Beyond PM 2.5 : The role of ultrafine particles on adverse health effects of air pollution. Biochim. Biophys. Acta 2016, 1860, 2844-2855. [CrossRef] 